\title{
Implementing Lean Methodology in a Power Cable Factory: A Case Study of a Low Voltage Cable
}

\author{
Mohammed Alamoudi, Rami H. Alamoudi \\ Department of Industrial Engineering, King Abdulaziz University, Jeddah, Saudi Arabia \\ Email: rhalamoudi@kau.edu.sa
}

How to cite this paper: Alamoudi, M. and Alamoudi, R.H. (2019) Implementing Lean Methodology in a Power Cable Factory: A Case Study of a Low Voltage Cable. American Journal of Industrial and Business Management, 9, 2083-2097.

https://doi.org/10.4236/ajibm.2019.912138

Received: October 30, 2019

Accepted: December 3, 2019

Published: December 6, 2019

Copyright $\odot 2019$ by author(s) and Scientific Research Publishing Inc. This work is licensed under the Creative Commons Attribution International License (CC BY 4.0).

http://creativecommons.org/licenses/by/4.0/

\begin{abstract}
The paper discusses the effects of implementing Lean methodology in a low voltage cable factory with the goal of enhancing production and time performance. Several different tools in the Lean methodology were used in this study, including planned maintenance, autonomous maintenance, focused improvement and OEE \& daily performance review. It is important to understand the current manufacturing process practiced in power cable factories. The practical effects and results of these tools are characterized in this study to help enable companies to use lean thinking. Practical implications; results indicate that applying the technique, manager can easily determine and eliminate manufacturing waster from the process. By enhancing the effectiveness of the process, they will be able to maximize resource allocation. Manufacturing sector has to validate the methodology for fruitful execution of lean technique. The adoption of Lean methodology attributed to successful execution of projects in minimizing changeover time. This implies that raw material delivery time is reduced. For instance, the use of this methodology can lead to 50 percent reduction time that is from $180 \mathrm{~min}$ to $90 \mathrm{~min}$. Other industries such as manufacturing industry can adopt this method to reduce the production and delivery time. Pilot examples of how to use lean methods are also described so that lean methods can be applied to other machines. Finally, the paper outlines the advantages of incorporating lean methodology into a company's projects and makes recommendations based on observations.
\end{abstract}

\section{Keywords}

Lean Methodology, Autonomous Maintenance, Focused Improvement, TPM, Overall Equipment Effectiveness, Power Cable Factory, Low Voltage Cable 


\section{Introduction}

Power cables are often used to transmit high voltages from one grid station to others. The consumption of cables has increased in recent years due to the installation of new power plants and grid stations across the country. Therefore, the production requirement has increased over the last few years. Power cable factories are working to achieve production requirements using advanced technology and effective manufacturing systems.

The purpose of this study is to improve the current manufacturing processes of the low voltage power cables to overcome the constraints associated with the current manufacturing system. The application of low voltage cables is increasing in complexity due to technological advancements that require improvements to cable harnesses. Thus, low voltage cable productivity has become critical for the power cable companies. The cable production rate of a company has decreased over the prior six months due to poor performance in the cable manufacturing process. Lean methodology is applied in this study to increase the working performance of the entire production system of low voltage cables. There are several different tools in the Lean methodology that were used in the study. Consumer loyalty and mishap records in the organization were used to measure changes in performance. "Lean" has been characterized as an orderly method to improve performance while reducing losses via the idea of "ceaseless change". Lean methods concentrate on the value in a stream of assets from the client's perspective. To compete in today's economy, an organization using lean methods will perform better than its rivals [1].

\section{Literature Review}

Lean methods are based on framing a perspective to reduce losses in business procedures and create another business stream for an organization. Using lean methods, an organization can enhance their performance and reduce their inputs, namely, base process duration, lead time and stock. This study of power cables was conducted at the University of Naples where lean methodology was used to eliminate the waste associated with the power cable manufacturing system and its maintenance. The study employed the cause and effect technique to identify the root cause of poor performance in the company's product line. The focus of this paper is on the maintenance portion of the lean methodology [2]. Contrary, the current paper used different lean methodology strategies such as planned maintenance, autonomous maintenance to enhance company performance. The study found out that these techniques are vital in enhancing firm performance and waste management. Lean methodology focuses on eight different types of waste that are associated with the production system of any product. These wastes are the major causes of defective products or poor-quality manufacturing. The first type of waste is related to the product known as overproduction [3]. The current paper established that overproduction is one of the issues that affect production effectiveness. Empirically, the lean methods align 
and manage all the activities in the production to reduce overproduction. By reducing the amount of waste released, quality is improved, and production time and resources are compressed. Another type of waste is waiting for production and occurs when part of the product is delayed during manufacturing, effectively stopping production until that part is either removed or progresses through production. In the power cable factory, the major focus was on overproduction, waiting, overprocessing and inventory of the low voltage cable products [4] [5]. These researchers' goals are in line with the current paper's aim, which emphasizes reducing waiting time and overproduction. The research adopted lean method techniques to reduce waiting time by establishing OEE that can control and see the bottle neck of the process and the performance of the production lines. Statistical control tools, including lean management, robust design, kano analysis, process map, affinity diagram, gauge $R \& R$, and design of experiment, were used to increase the mean average electrical resistance in the cable product, saving the raw material, copper, which carries the most cost of cable production [6]. The process mapping of finding for finding the source of variation was helpful tool that is included in identifying the machine assembly and sub-assembly points. As electricity demand has increased in Germany, production has decreased due to shut downs of nuclear power plants and changes to new renovated energy production methods. Thus, new solutions, such as grouping power cables in tunnels by building a movable cable factory, are needed to save transportation costs, reduce cable joints, and increase cable reliability [7]. In our paper we used Lean methods to integrate set of process that helps in accomplishing production by reducing the production costs. To address cost of production in Power Cable Factory, lean methodology utilizes numerous strategies to accomplish this goal. Lean manufacturing focuses on waste reduction using the $4 \mathrm{P}$ concept (Problem Solving, People and Partners, Process, and Philosophy) [8] [9] [10]. Nahili used the OEE indicator to improve the efficiency of the production line which is a very good tool that can be used with solid actions of improvements [11]. Cable manufacturing organization used TPM to help the current maintenance practice by looking into the status of 27 machines and improve them with unique solution which can be used in this paper to see the highest ranked machine with poor condition [12]. Two pillars have been used autonomous maintenance and focused improvement TPM implementation reduces the downtime from 7730.80 minutes per month to 4942.20 minutes per month, the loss of the scrap from 4570.00 kilograms per month to 2236.67 kilograms per month. The OEE is increased from 67.21 percent to 72.14 percent [13].

\section{Research Methods}

This study reviews 5 lean principles: identify value, value stream mapping, create flow, establish pull and seek perfection, as described in Figure 1. This study applies the total productive maintenance (TPM) pillars of planned maintenance, autonomous maintenance and focused improvement. Each pillar was applied 


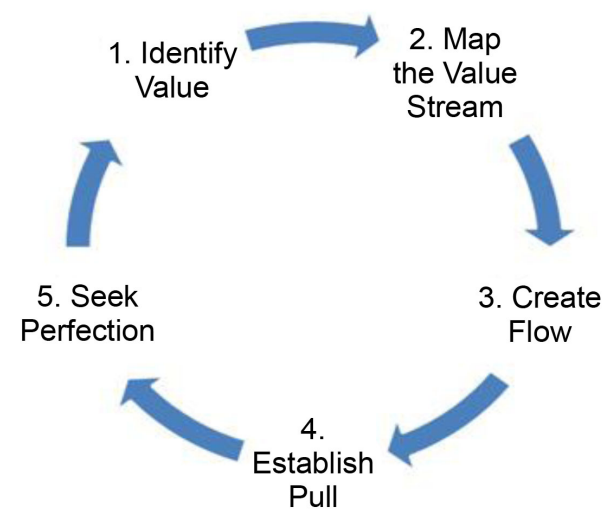

Figure 1. Lean principles.

with its own sequence of activities to develop the manufacturing process, to solve mass production problems, and to exceed customer satisfaction.

\subsection{Applied Methods}

This study was planned in 3 phases, as described in Figure 2.

- Frame-up.

- Identify \& Execute.

- Evaluate \& Maintain.

We briefly explain the scope of work covered in each of the phase to implement the lean practices to achieve improved productivity and reduce downtime.

\subsubsection{Frame-Up}

The goal of this phase was to select and assign a main team. Then, machines were ranked in order based on different criteria such as capacity usage, situation, and obstruction process. Each machine was then installed in order, and both time and resources were specified for each machine group. The OEE measurement and reporting system, including tools and meetings, was then set up, creating a powerful Lean training for the main team.

\subsubsection{Identify \& Execute}

The objective of this phase was to implement different techniques to select existing machines. We also ensured that the main team was supported during implementation. Then, we identified and executed the TPM foundation, including the Life Table, and created a standardized operating procedure (SOP).

\subsubsection{Evaluate \& Maintain}

The goal of this phase was to create a performance review system with a defined frequency and accountability. Routine audits were also initiated to ensure that results were being sustained as shown in Table 1.

\subsection{Tools Selection}

We decided to implement the key pillars of the TPM framework as shown in Figure 3 and other lean methodologies, such as standardization, Visual Management 
Table 1. Criteria for evaluating equipment.

\begin{tabular}{|c|c|c|c|}
\hline Attribute & A Rank & B Rank & C Rank \\
\hline $\begin{array}{l}\text { S-Safety and } \\
\text { environmental effects }\end{array}$ & $\begin{array}{l}\text { Failure would cause significant } \\
\text { environmental issues in circumferential } \\
\text { place }\end{array}$ & $\begin{array}{l}\text { Failure would cause some } \\
\text { safety and environmental issues } \\
\text { in circumferential place }\end{array}$ & $\begin{array}{l}\text { Failure would cause no safety or } \\
\text { environmental issues in circumferential } \\
\text { place }\end{array}$ \\
\hline Q-Quality and revenue & $\begin{array}{l}\text { Failure would cause abnormal product to } \\
\text { be produced or significantly affect revenue }\end{array}$ & $\begin{array}{l}\text { Failure would cause quality } \\
\text { variation or affect revenue } \\
\text { slightly }\end{array}$ & $\begin{array}{l}\text { Failure would affect neither quality nor } \\
\text { revenue }\end{array}$ \\
\hline $\begin{array}{l}\text { W-Working (operating) } \\
\text { condition }\end{array}$ & 24 hours working & 7 to 14 hours working & irregular, working only \\
\hline $\begin{array}{l}\text { A-Delay factor } \\
\text { (opportunity) condition }\end{array}$ & $\begin{array}{l}\text { Failure would shut down the entire } \\
\text { factory }\end{array}$ & $\begin{array}{l}\text { Failure would shut down } \\
\text { relevant system only }\end{array}$ & $\begin{array}{l}\text { Stand-by unit available/more economical } \\
\text { to wait for failure and then repair }\end{array}$ \\
\hline M-maintainability & $\begin{array}{l}\text { Repair time: } 4 \text { hours or more } \\
\text { Repair cost: over } 2400 \text { USD }\end{array}$ & $\begin{array}{l}\text { Repair time: } 1 \text { - } 4 \text { hours } \\
\text { Repair cost: } 400 \text { - } 2400 \text { USD }\end{array}$ & $\begin{array}{l}\text { Repair time: less than } 1 \text { hour } \\
\text { Repair cost: less than } 400 \text { USD }\end{array}$ \\
\hline
\end{tabular}

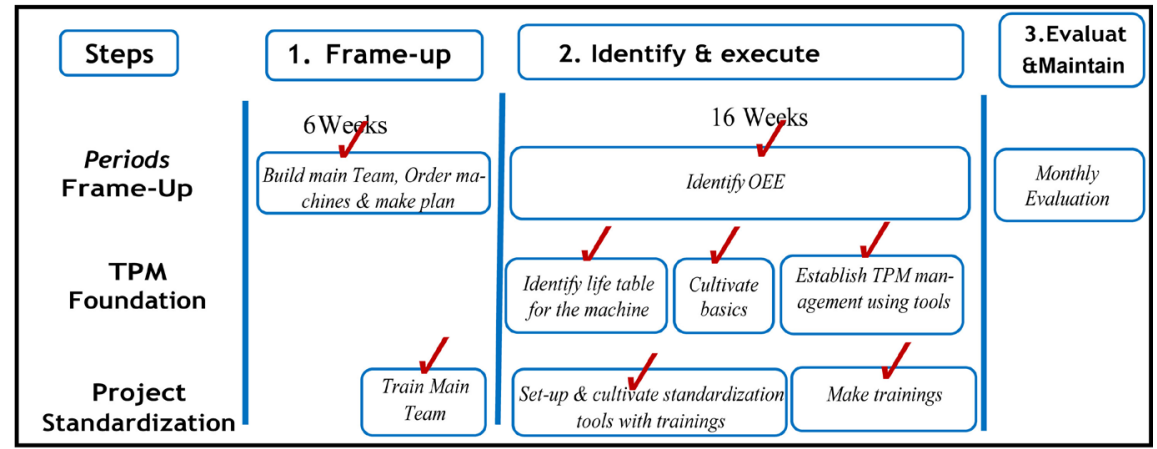

Figure 2. Project plan.

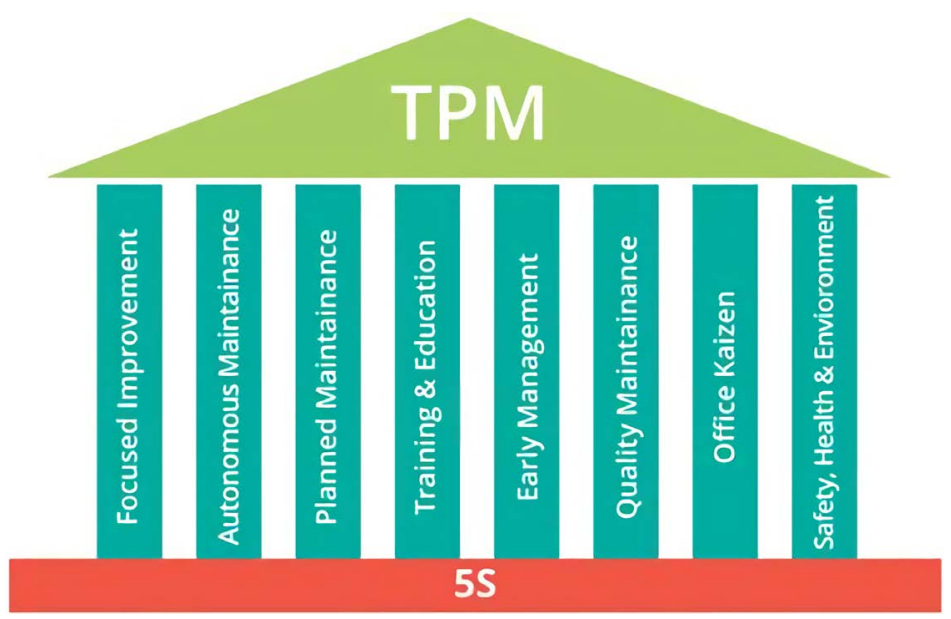

Figure 3. TPM pillars.

and SMED, on a machine as a proof of concept. This decision was made considering that maximum benefit is achieved through the application of these elements, which directly impact the performance of the manufacturing process and 
address issues faced in managing demand.

In TPM, pillars of planned maintenance, autonomous maintenance and focused improvement were implemented. Each pillar had its own sequence of activities.

\subsubsection{Planned Maintenance}

The planned-maintenance objective was to identify all the tasks required to maintain the machines based on the experience of the manufacturing team and the recommendations of the original equipment manufacturer. Another objective was to have data gathered to support decision making and maintain the equipment effectively.

First, each piece of equipment was ranked to determine its impact on process performance and other factors, such as safety, quality, downtime, frequency of failures, and maintenance cost, as described in Figure 4. The machine drum twister was selected for proof of concept based on its ranking. Then, a cross functional team that consisted of production and maintenance department staff was set up to create awareness about the equipment and machinery. They focused on identifying all the assemblies and subassemblies in sequential order following the product flow.

During identification of the various parts of the machine, observations were made regarding the condition of the machinery. Parts requiring replacement and parts needing future for maintenance were also identified. The team then developed a life table to identify the required maintenance tasks for each assembly of the machine, what tools and spare parts are required, and important details about the supplier and cost of the parts.

The team also analyzed the amount of time required from the maintenance staff and from the machine operators to perform the identified tasks. Based on all these data, a maintenance schedule was created for each piece of equipment. The planned maintenance schedule was implemented and followed to improve equipment condition and restore the machinery to its original condition.

\subsubsection{Autonomous Maintenance}

In this pillar, efforts were directed towards improving operator skill sets so that they could perform small maintenance tasks and reduce time requirements of the maintenance staff. An important outcome of this implementation is that operators can prevent process downtime by taking timely actions through cleaning, lubrication, inspection and tightening activities daily. As described in Figure 5, seven autonomous maintenance steps were followed and began with an initial cleaning to eliminate dust and dirt and expose any hidden defects. Contamination sources of dust and dirt were then investigated to prevent accumulation of the equipment.

Routine cleaning and standards were then established to ensure that the basic three conditions of cleaning, lubrication and tightening were performed daily. The capability of operators was also increased by providing trainings to understand 


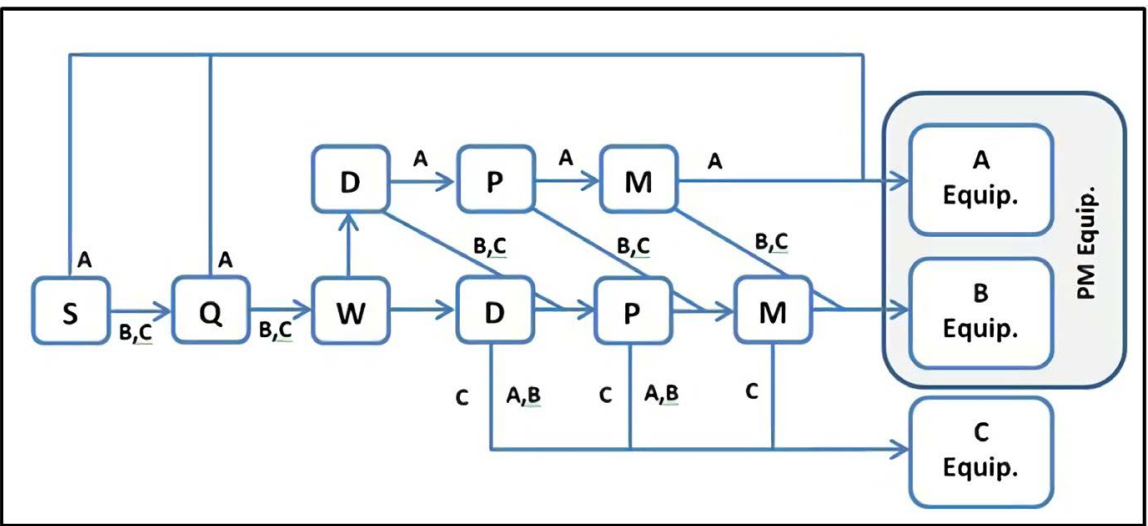

Figure 4. Evaluation of machine ranking.
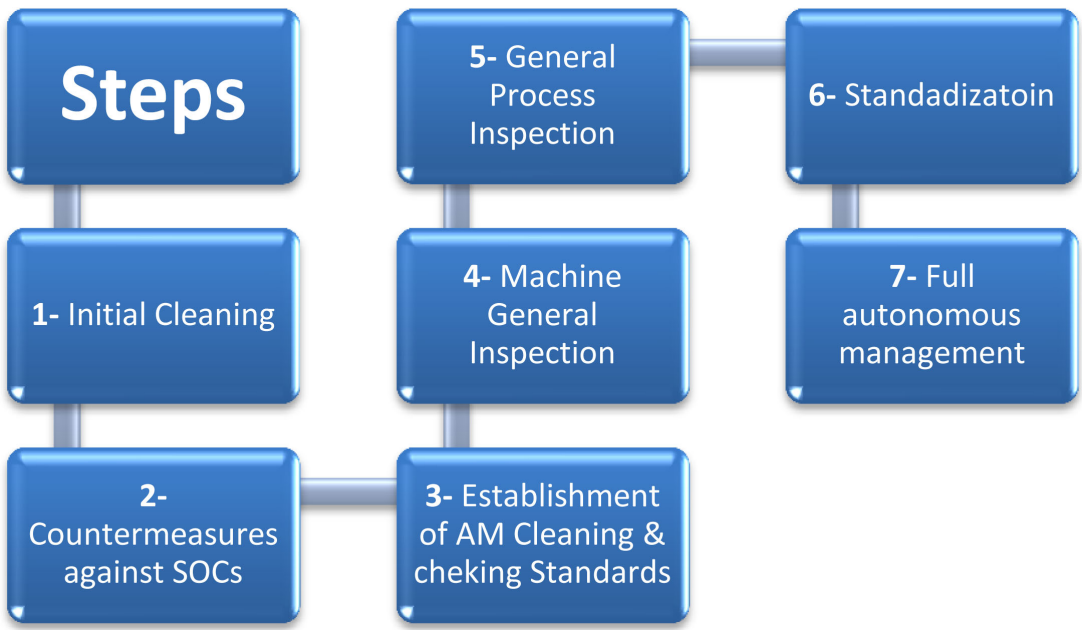

Figure 5. Autonomous maintenance steps.

best practices in inspecting the equipment. Standard procedures and work instructions were created to support operators in performing daily maintenance tasks.

\section{Focused Improvement}

One of the hallmarks of the Lean method is to involve employees in improvement initiatives. The team initiated the A3 problem solving and Kaizen program. The A3 problem-solving template is a tool for systematically and thoroughly identifying a problem, fixing it, and making sure it does not recur. The method follows the Plan-Do-Check-Act cycle, which includes the following steps:

1) Define the problem or the issue by illustrating when and where it appeared, what its frequency is, under which conditions it appears, and what the purpose of solving the problem is;

2) Determine the cost of the problem by determining time and quality loss;

3) Break down the problem until you reach its root cause;

4) Identify corrective actions;

5) Implement those actions and escalate the problem to a manager if the due date is exceeded; 
6) Check the result based on quantitative data based on cost, time and quality;

7) Follow up on any recurring issues after root cause actions are implemented.

\subsubsection{Overall Equipment Effectiveness (OEE) \& Daily Performance Review}

In theory, production equipment is designed to perform at an expected level of productivity; however, the actual performance is typically much lower than the theoretical expected performance. This is called "invisible productivity loss", which must be characterized and examined thoroughly. According to TPM, these invisible losses can be categorized into six major loss types. TPM uses overall equipment effectiveness to highlight these losses so that the team can focus on creating a metric for production.

We began training employees on how to calculate OEE according to Table 2 by calculating availability, which is the time the machine is available for production performance; the speed at which the machine is operating; and the quality of the machine's performance. The product of these factors was used to determine the machine's OEE, as shown in Figure 6.

Log sheets were used to capture important information. Operators were responsible for inputting data into the log sheets, which were then used by data operators to upload into the calculation sheet. A given week was then reviewed by the production management team to determine the performance of the line in the previous week and take remedial actions to improve the OEE.

Daily reviews were established for this purpose, and visual displays of the shared folder were put in the production area. The goal was to make process performance visible to everyone and to understand what problems existed.

Table 2. OEE calculation.

\begin{tabular}{|c|c|c|c|}
\hline \multicolumn{4}{|c|}{ OEE (Availability $\times$ Performance $\times$ Quality) } \\
\hline \multirow{2}{*}{ Availability } & Actual Operating time & \multicolumn{2}{|c|}{ Planned production time - unplanned downtime } \\
\hline & $\overline{\text { Planned production time }}$ & \multicolumn{2}{|c|}{ Total available time - planned downtime } \\
\hline \multirow{2}{*}{ Performance } & Actual Run Rate & \multicolumn{2}{|c|}{ Total produced/actual run speed } \\
\hline & \multicolumn{3}{|c|}{$\overline{\text { Ideal } / \text { max Run Rate }}=\overline{\text { Ideal/max.able to be produced on equipment } / \text { run speed }}$} \\
\hline \multirow{2}{*}{ Quality } & \multirow{2}{*}{\multicolumn{3}{|c|}{$\frac{\text { Good material produced }}{\text { Total produced }}=\frac{\text { Good material produced }}{\text { Total produced }}$}} \\
\hline & & & \\
\hline $\begin{array}{l}\text { Choose OEE } \\
\text { champion }\end{array}$ & $\begin{array}{l}\text { Training on } \\
\text { OEE idea }\end{array}$ & $\begin{array}{l}\text { Start OEE data } \\
\text { collection tools }\end{array}$ & $\begin{array}{l}\text { Begin Root } \\
\text { cause analysis }\end{array}$ \\
\hline $\begin{array}{l}\text { As it is hard to } \\
\text { change, we need } \\
\text { to engage } \\
\text { production } \\
\text { operators }\end{array}$ & $\begin{array}{l}\text { Training class to } \\
\text { share knowledge } \\
\text { about the OEE idea } \\
\text { and how to do the } \\
\text { measurement with } \\
\text { the team }\end{array}$ & $\begin{array}{l}\text { Begin training on } \\
\text { using tools and on } \\
\text { how to fill,"read" } \\
\text { and analyze the } \\
\text { data }\end{array}$ & $\begin{array}{l}\text { Training on root } \\
\text { cause analysis } \\
\text { tools such as } 5 \mathrm{~W} \\
\text { and PDCA, then } \\
\text { make } \\
\text { documentation }\end{array}$ \\
\hline
\end{tabular}

Figure 6. Determining the machine's OEE. 


\subsection{Single Minute Exchange of Dies (SMED)}

As an outcome of the OEE implementation, the team identified that machine availability is significantly impacted by personnel changeovers and scheduled maintenance activities. Therefore, the team used a tool of Lean methodology called SMED, which required a group to implement SMED using the following steps:

1) Understand and evaluate the current situation;

2) Register the changeover;

3) Analyze the changeover and apply ECRS (Eliminate, Combine, Reduce and Simplify) to the tasks;

4) Identify actions to implement;

5) Execute the actions;

6) Standardize the solutions.

\section{Results}

As part of the application of TPM, a core team was assigned and trained in Lean theory and practical application. A detailed implementation plan with timeline and resources was developed. The OEE measurement and reporting system were created, and a team was trained on TPM concepts and documentation standards to allow them to manage other machines in the future.

The team was able to implement the methods on one machine as an experiment on successful implementation. TPM infrastructure and standardization were also setup for other machines in the factory; the core team helped to support, evaluate and make the necessary changes.

\subsection{Ranking Results}

- The cross-functional and core teams agreed on equipment rankings, which have been approved.

- Twenty-four machines were identified as Rank A, as shown in Table 3 and Table 4.

- The groups of machines in Rank A include the following:

- Wire drawing and tinning equipment (6);

- Pairing and assembly equipment (7);

- Extrusion and insulation equipment (8);

- Packing equipment (3).

- The plan is to start with the extrusion machines (the largest group with Rank A), followed by the assembly line machines (the second largest group with Rank A).

\subsection{Machine Restoration}

Machine restoration was as described in Figure 7.

- Improved operator morale resulted in sustained adherence to standards on drum twister and extrusion machines. Autonomous maintenance implementation on both types of machines and improvement in adherence to SOPs increased by $81 \%$. 
Table 3. Machine ranking with A rank.

\begin{tabular}{|c|c|c|c|c|c|c|}
\hline & Machine & Operations & Quality & Safety & Maintenance/cost & RANK \\
\hline 1 & R.BD-1 (NIEHOFF) & A & $\mathrm{C}$ & $\mathrm{C}$ & A & A \\
\hline 7 & M.W.D-I (NIEHOFF) & A & $\mathrm{C}$ & $\mathrm{C}$ & A & A \\
\hline 8 & MWD-II (SICTRA) & A & $\mathrm{C}$ & $\mathrm{C}$ & A & A \\
\hline 9 & MWD-III (SICTRA) & A & $\mathrm{C}$ & $\mathrm{C}$ & A & A \\
\hline 11 & Tinning M/C (OTOMAC)-1 & B & $\mathrm{C}$ & B & A & A \\
\hline 12 & Tinning M/C (OTOMAC)-2 & A & $\mathrm{C}$ & B & B & A \\
\hline 52 & MTO-1250-I (LESMO) & A & $\mathrm{C}$ & $\mathrm{C}$ & A & A \\
\hline 54 & MTO-1600-1 (LESMO) & A & $\mathrm{C}$ & $\mathrm{C}$ & A & A \\
\hline 55 & DTO-1250 (LESMO) & A & $\mathrm{C}$ & $\mathrm{C}$ & A & A \\
\hline 57 & DT-1600 (LESMO) & A & $\mathrm{C}$ & $\mathrm{C}$ & A & A \\
\hline 58 & DT-1800 (LESMO) & A & $\mathrm{C}$ & $\mathrm{C}$ & A & A \\
\hline 59 & DT-1800 (POURTIER) & A & $\mathrm{C}$ & $\mathrm{C}$ & A & A \\
\hline 60 & DT-2000 (POURTIER) & A & $\mathrm{C}$ & $\mathrm{C}$ & A & A \\
\hline 96 & J.R.-HCV LINE & A & $\mathrm{C}$ & $\mathrm{C}$ & A & A \\
\hline 97 & J.R. $65 / 80 \mathrm{MM}$ & A & $\mathrm{C}$ & C & A & A \\
\hline 100 & Nokia-1 $(80 \mathrm{~mm})$ & A & $\mathrm{C}$ & $\mathrm{C}$ & A & A \\
\hline 101 & Nextrom-80 mm & A & $\mathrm{C}$ & $\mathrm{C}$ & A & A \\
\hline 102 & Tandem line & A & $\mathrm{C}$ & $\mathrm{C}$ & A & A \\
\hline 107 & J.R. $100 \mathrm{MM}$ & A & $\mathrm{C}$ & $\mathrm{C}$ & A & A \\
\hline 109 & Mapre-100 mm & A & $\mathrm{C}$ & $\mathrm{C}$ & A & A \\
\hline 110 & Nokia-2 $(100 \mathrm{~mm})$ & A & $\mathrm{C}$ & $\mathrm{C}$ & A & A \\
\hline 120 & Skaltek Mini Pack & A & $\mathrm{C}$ & C & A & A \\
\hline 121 & Skaltek D.P.Line-1 & A & C & $\mathrm{C}$ & A & A \\
\hline 131 & RP-3 (PS) & A & $\mathrm{C}$ & $\mathrm{C}$ & A & A \\
\hline
\end{tabular}

Table 4. Results of machine ranking.

\begin{tabular}{|c|c|c|c|c|c|}
\hline \multicolumn{2}{|c|}{ Total \# of machines } & $\begin{array}{c}\text { Total \# of machines } \\
\text { ranked A }\end{array}$ & \multicolumn{2}{|c|}{$\begin{array}{c}\text { Total \# of machines } \\
\text { ranked B }\end{array}$} & $\begin{array}{c}\text { Total \# of machines } \\
\text { ranked C }\end{array}$ \\
\hline 134 & & 24 & 60 & & 50 \\
\hline $100 \%$ & & $18 \%$ & $45 \%$ & & $37 \%$ \\
\hline Machine & $\begin{array}{l}\text { Initial cleaning } \\
\text { and inspection }\end{array}$ & $\begin{array}{c}\text { Initial } \\
\text { Restoration }\end{array}$ & $\begin{array}{c}\text { Standardize } \\
\text { autonomous and } \\
\text { preventive } \\
\text { maintenance }\end{array}$ & $\begin{array}{l}\text { Implement new } \\
\text { SOPS }\end{array}$ & $\begin{array}{l}\text { Documentation } \\
\& \\
\text { communication }\end{array}$ \\
\hline $\begin{array}{c}\text { Define } \mathrm{m} / \mathrm{c} \\
\text { assemblies \& } \\
\text { subassemblies, } \\
\text { create machine } \\
\quad \text { layout }\end{array}$ & $\begin{array}{l}\text { Inspect \& clean } \\
\text { to detrmine the } \\
\text { abnormalities } \\
\text { with the CILR } \\
\text { points }\end{array}$ & $\begin{array}{c}\text { Ensure the } \\
\text { availability of } \\
\text { parts in } \\
\text { warehouse, start } \\
\text { restoration and } \\
\text { replacement and } \\
\text { if not available, } \\
\text { purchase it }\end{array}$ & $\begin{array}{l}\text { Write necessary } \\
\text { SOPs, modify } \\
\text { after shop floor } \\
\text { visit, write task } \\
\text { checklists }\end{array}$ & $\begin{array}{l}\text { Maintenance } \\
\text { and production } \\
\text { performed daily, } \\
\text { weekly, and } \\
\text { monthly; } \\
\text { autonomous and } \\
\text { preventive tasks } \\
\text { per the defined } \\
\text { SOP }\end{array}$ & $\begin{array}{l}\text { Record as } \\
\text { before and after } \\
\text { or one-point } \\
\text { lessons; wins } \\
\text { are financially } \\
\text { validated; } \\
\text { create training }\end{array}$ \\
\hline
\end{tabular}

Figure 7. Machine restoration approach. 
- A cross-functional team, including production and maintenance department staff, was created to raise awareness and create positive expectations among the designated team. The team defined machine assemblies and subassemblies based on their experience for later comparison against the OEM (Original Equipment Manufacturer) manuals and challenged by directly observing the machine on the shop floor. All machine assemblies and subassemblies were drawn graphically to represent each assembly's location using color coding that identified moving parts from static parts.

- During the shop floor observations the team classified the parts as follows:

- Parts that are functional;

- Parts that need to be replaced;

- Parts that need a plan for maintenance.

To achieve full restoration of a piece of equipment, a plan including the required time and resources was created based on confirmed delivery dates of replacement parts from the purchasing department.

The team gathered any existing documentation available about the machine, including but not limited to original equipment manufacturer manuals, diagrams, tables, and any technical information available in the maintenance department related to the equipment. The team compared the instructions and tasks suggested by the OEM with the tasks already captured in the life table. The team reviewed and assessed the document's "usability". Documents must be created for use as training material for new hires, front line operators and any person that has contact with the equipment. Therefore, the document created must be user-friendly, even for users who cannot read or write. The team performed shop floor observations to assess the level of understanding and activity sequences and to adjust frequencies and task times. The team updated the developed standards to adjust them based on shop floor observations to ensure that they were attainable.

\subsubsection{Drum Twister}

1) Observations

- The machine is more than 10 years old. As shown in Figure 8.

- Preventative measures for safety and health, such as warning lights, an emergency-stop button, and basics for cleaning, tightening and lubrication, are not available.

- Pneumatic systems and gauges are not working.

- Many temporary fixes have been performed.

- Bearings did not rotate freely.

- Sliding shafts have been painted over.

- The restoration of the drum twister machine reduced breakdowns and increased speed (production capacity increased by $35 \%$ per month), as shown in Table 5.

\subsubsection{Extrusion Machine}

After doing the restoration for extrusion machine as per Figure 9 which is showing 


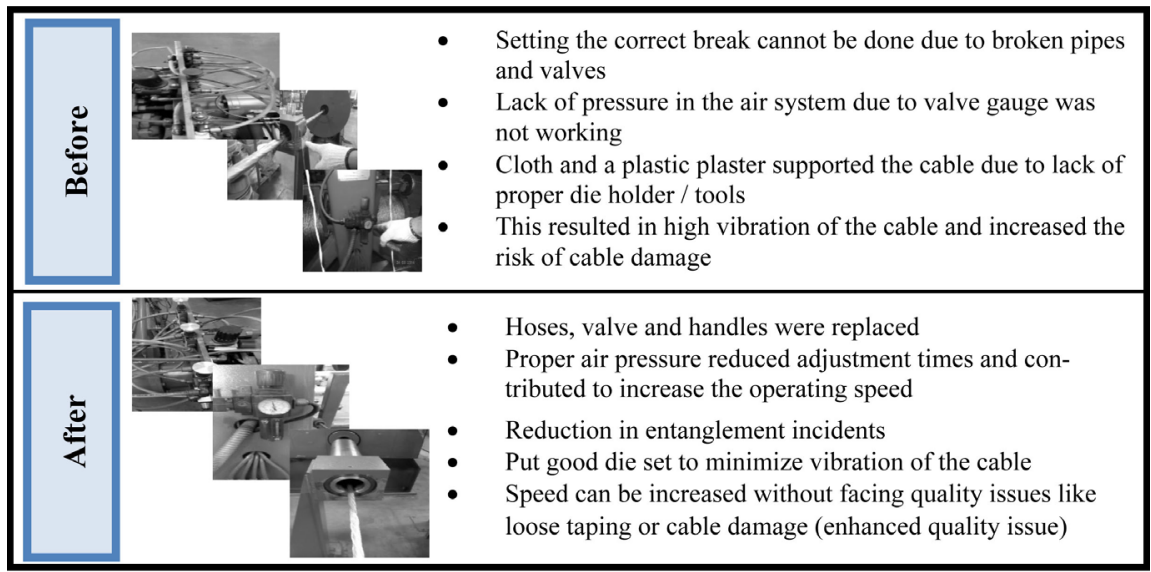

Figure 8. Drum twister restoration.

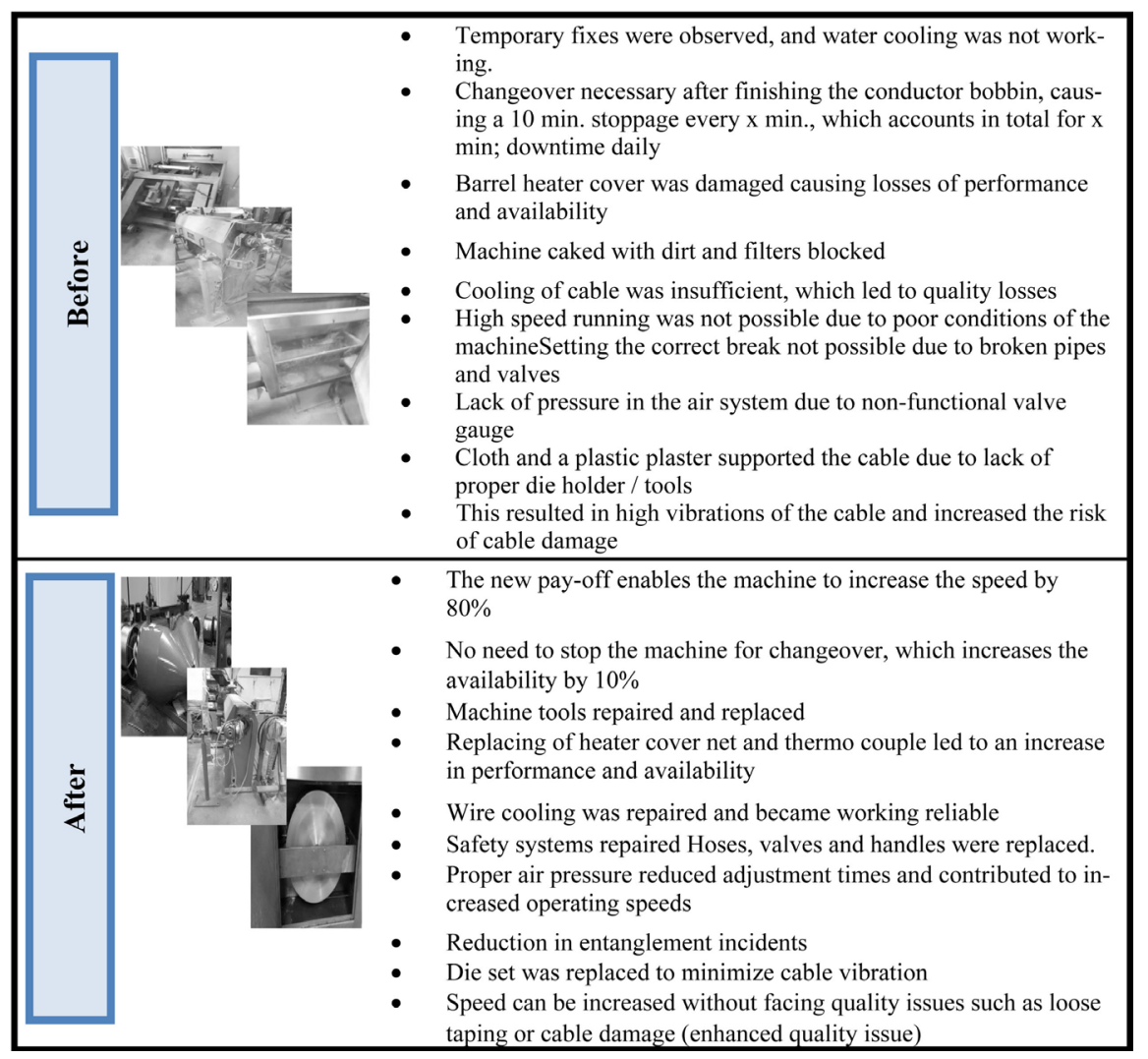

Figure 9. Extrusion machine restoration.

the before and after machine condition the new pay-off enables the machine to increase the speed by $80 \%$ as shown in Table 6 and need to stop the machine for changeover which increases the availability by $10 \%$. Moreover, the safety system is improved and repaired.

\subsection{Changeover Reduction Using SMED}

Single-minute Digit exchange of die (SMED) is a lean production method that helps in minimizing waste in manufacturing procedure as shown in Figure 10. It 
Table 5. Increase in speed yielded a $35 \%$ increase in production capacity per month.

\begin{tabular}{|c|c|c|c|}
\hline Description & Factor & Qty & UOM \\
\hline Total production Jan to Aug 2017 & & 2800 & $\mathrm{~km}$ \\
\hline Average production per month & 8 & 350 & $\mathrm{~km}$ \\
\hline Average production-assembly & $60 \%$ & 210 & $\mathrm{~km}$ \\
\hline Average production—armoring & $40 \%$ & 140 & $\mathrm{~km}$ \\
\hline Possible production after speed trial speed increase-assembly & $50 \%$ & 105 & $\mathrm{~km}$ \\
\hline Possible production after speed trial speed increase-armoring & $29 \%$ & 40 & $\mathrm{~km}$ \\
\hline Total increase in production capacity & & 145 & $\mathrm{~km}$ \\
\hline Safety factor due to product mix & & $15 \%$ & $\%$ \\
\hline $\begin{array}{l}\text { Average possible production capacity increase } \\
\text { based on speed increase }(\mathrm{km})\end{array}$ & & 123 & $\mathrm{~km}$ \\
\hline \multicolumn{2}{|c|}{ Average possible production capacity increase based on speed increase (\%) } & $35 \%$ & $\mathrm{~km}$ \\
\hline
\end{tabular}

Table 6. Increasing speed and availability yielded an $80 \%$ increase in production capacity per month.

\begin{tabular}{cccc}
\hline Description & Factor & Qty & UOM \\
\hline Total production Jan 2017 to Mar 2018 & & 65,500 & $\mathrm{~km}$ \\
Average production per month & 15 & 4367 & $\mathrm{~km}$ \\
Average production - extrusion & $100 \%$ & 4367 & $\mathrm{~km}$ \\
Baseline beginning of project & & 308 & $\mathrm{mpm}$ \\
Speed test trial result (15/04/2018) & 600 & $\mathrm{mpm}$ \\
$\begin{array}{c}\text { Possible production after speed trial speed increase } \\
\text { Safety factor due to product mix }\end{array}$ & $95 \%$ & 4149 & $\mathrm{~km}$ \\
Average possible production capacity increase & $15 \%$ & $\%$ \\
based on speed increase (km) & 3526 & $\mathrm{~km}$ \\
Average possible production capacity increase based on speed increase (\%) & $80 \%$ & $\mathrm{~km}$ \\
\hline
\end{tabular}

\begin{tabular}{|c|c|c|}
\hline$\frac{0}{\frac{0}{0}}$ & 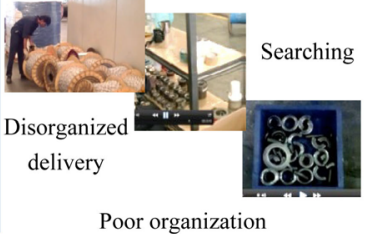 & $\begin{array}{l}\text { - Raw materials transferred in a mixed up way and time is } \\
\text { lost for searching and verification } \\
\text { - } \quad \text { littered layout makes walking around difficult for opera- } \\
\text { tors } \\
\text { - Time lost for arranging materials for use and no hand } \\
\text { tools available and time lost for quality test } \\
\text { - Machine tooling must be restored from the store }\end{array}$ \\
\hline 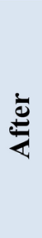 & $\begin{array}{l}\text { Tools \& consu- } \\
\text { mables } \\
\text { on hand }\end{array}$ & $\begin{array}{l}\text { - Raw materials delivered clearly and marked in sequence } \\
\text { ready for use from staging area } \\
\text { - Clear layout designed with drop points } \\
\text { - Tachine tooling order system defined } \\
\text { Tools required for hand and machine defined and installed } \\
\text { line side } \\
\text { Technical solutions inspected for loading/unloading bob- } \\
\text { bins and joining cables }\end{array}$ \\
\hline
\end{tabular}

Figure 10. SMED. 
offers a quick and effective way of transforming industrial procedure from present production to the next production. SMED is a lean tool that helps in reducing the amount time taken in changing one process to another. Apart from enhancing cycle time, SMED is vital in reducing cost and promoting flexibility in the process. The successful implementation of the project resulted in reduced changeover time. Much time was lost during changeovers due to the disorganized delivery of raw materials and poor tooling organization and layout. After applying SMED, a 50\% reduction from $180 \mathrm{~min}$ to $90 \mathrm{~min}$ was achieved.

\subsection{Deploying the OEE Measurement Tools and Processes}

- A team was trained on OEE concepts.

- The team defined the best process, roles and responsibilities for the people involved.

- A new log sheet was defined to avoid recording duplicates.

- The team was trained on the OEE database to ensure measurement was established.

- Meetings to discuss the root cause of major failures were organized.

\section{Recommendations}

The results of applying Lean methods are significantly better than what we hypothesized. The team's capabilities and practical experiences gained through implementation on the pilot machine have prepared the team to implement lean practices on other machines. The proof of concept has shown the team the improvement potential of lean methods. Thus, management must continue with the program and support the team in implementing lean methods in other areas of the factory. We also recommend the following:

1) Support the auditing system to follow standards deployed using regular meetings (operations-AM \& PM).

2) Communicate the TPM team roles and responsibilities, and make more time for training.

3) Kick-off weekly OEE reporting with top issues analysis and solutions.

\section{Conclusion}

Implementing lean methodology in a power cable factory increased process performance and production. The results of this study provide hope for the future of cable manufacturing in terms of quality and quantity. Additional actions, standard procedures and follow-up practices to improve overall factory efficiency are still required. The PDCA methodology has helped to determine reliability and ensure good reliability of the system.

\section{Conflicts of Interest}

The authors declare no conflicts of interest regarding the publication of this paper. 


\section{References}

[1] Chanarungruengkij, V., Saenthon, A. and Kaitwanidvilai, S. (2017) Application of Lean Manufacturing System: A Case Study of Control Cable Manufacturing. Proceedings of the International Multi Conference of Engineers and Computer Scientists, Hong Kong, 1-5.

[2] Romano, E. (2013) Lean Maintenance Model to Reduce Scraps and WIP in Manufacturing System: Case Study in Power Cables Factory. WSEAS Transactions on Systems, 12, 650-666.

[3] Paramesh, S.B. (2013) Lean Six Sigma Implementation in Cable Harness Manufacturing. International Journal of Mechanical and Production Engineering, 1, 49-56.

[4] Bartlett, A.D., Daly, J.J., Gregory, B. and Phillips, S. (2013) Cost Reductions in Power Cable Systems Using Lean Cable Technology. BICC Cables Limited.

[5] Karim, A. and Arif-Uz-Zaman, K. (2013) A Methodology for Effective Implementation of Lean Strategies and its Performance Evaluation in Manufacturing Organizations. Business Process Management Journal, 19, 169-196. https://doi.org/10.1108/14637151311294912

[6] Azad, P.S. and Mokhlesi, R. (2009) Statistical Quality Control in Cable Industry Case Study: Copper Consumption Reduction in Nexans IKO Sweden. Master of Science, University of Borås/School of Engineering, Borås, Sweden.

[7] Severengiz, M., Sprenger, T. and Seliger, G. (2016) Challenges and Approaches for a Continuous Cable Production. Procedia CIRP, 40, 18-23. https://doi.org/10.1016/j.procir.2016.01.040

[8] Liker, J.K. (2010) The Toyota Way. McGraw-Hill Publication, New York.

[9] Bhamu, J. and Sangwan, K.S. (2014) Lean Manufacturing: Literature Review and Research Issues. International Journal of Operations \& Production Management, 34, 876-940. https://doi.org/10.1108/IJOPM-08-2012-0315

[10] Jasti, N. and Kodali, R. (2015) Lean Production: Literature Review and Trends. International Journal of Production Research, 53, 867-885.

https://doi.org/10.1080/00207543.2014.937508

[11] En-Nhaili, A., Meddaoui, A. and Bouami, D. (2016). Effectiveness Improvement Approach Basing on OEE and Lean Maintenance Tools. International Journal of Process Management and Benchmarking, 6, 147-169. https://doi.org/10.1504/IJPMB.2016.075599

[12] Mabohwa,C. (2014) Total Productive Maintenance (TPM) Application for Cable Manufacturing Organization. 2014 6th International Conference on Mechanical, Production \& Automobile Engineering, 27-28 November 2014.

[13] Joochim, O. and. Meekaew, J. (2016) Applying Total Productive Maintenance in Aluminium Conductor Stranding Process. Journal of Industrial Engineering and Management Science, 1, 19-42. https://doi.org/10.13052/jiems2446-1822.2016.002 